\title{
Locking and Control: A Door Bolt Sealing from Hierakonpolis
}

\author{
Richard Bussmann
}

\begin{abstract}
The paper discusses an unpublished door bolt sealing from Hierakonpolis excavated in 1978. The sealing pattern belongs to a visual tradition originating in the predynastic period. The proposed reconstruction of the locking system combines analysis of the reverse side of the sealing with archaeological evidence of doors and door bolts. Public performance is suggested for sealing practice and control to function socially.
\end{abstract}

In 1978, a team led by W. Fairservis on behalf of the American Research Center in Egypt found a clay sealing in quadrant $8 \mathrm{~N} 6 \mathrm{~W}$ located in the North Western corner of the temple enclosure wall of Hierakonpolis (fig. 1). ${ }^{1}$ It has the find number 26-78-118 and was officially registered as number 114 on 27 February $1978 .^{2}$ The object is not mentioned in Fairservis' preliminary reports. ${ }^{3}$ Information on archaeological context is gleaned from the entry in the register book only.

The sealing is completely preserved, $5.7 \mathrm{~cm}$ high, $3.9 \mathrm{~cm}$ broad and $1.8 \mathrm{~cm}$ deep (figs. 2-3). It has a light brown to reddish color (Munsell 5YR 5/4), which indicates that it was exposed to the heat of a fire or a glowing at some point.

\section{The Locking System}

The reverse side of the sealing shows the impressions of a door bolt, a cord, and a door wing. The angular door bolt has a smooth surface and was carefully made, probably of wood. The impression of the door wing, although not as even as the impression of the bolt, has a fibred texture deriving from wood. The cord ran parallel to and on top of the bolt.

Current reconstructions suggest that door bolt sealings were applied onto the area of contact between the bolt and the door and that the bolt was held in place by a cramp on the door and another cramp on the adjacent wall or on a second door wing. ${ }^{4}$ However, what remains unexplained for the

1 The grid reference system is not used consistently in the two reports quoted in n. 3. The report of the 1978 season, published in 1983, refers to quadrants by quoting the grid lines to their South East, i.e., the crossing of lines $8 \mathrm{~N}$ and $6 \mathrm{~W}$ is located in the bottom left corner of quadrant 8 N6W. The report of the 1981 season, published in 1986, refers to the North East corner of a quadrant, i.e., the crossing of lines $17 \mathrm{~N}$ and $6 \mathrm{~W}$, for example, is located in the top left corner of quadrant $17 \mathrm{~N} 6 \mathrm{~W}$.

${ }^{2}$ I would like to thank Renee Friedman for alerting me to the current location of the sealing in the magazine of Elkab and offering accommodation for two weeks in February 2014. I also wish to thank Ramadan Hassan Ahmed and Amal Abdullah Ahmed Hamed for facilitating access to the material and supporting my research in the magazine in every possible way.

${ }^{3}$ Walter A. Fairservis, Jr., The Hierakonpolis Project Season January to March 1978. Excavation of the Temple Area on the Kom el Gemuwia (Poughkeepsie, NY, 1983); idem, The Hierakonpolis Project. Season January to March 1981. Excavation on the Kom Gemuwia. Excavation of the Archaic Remains East of the Niched Gate (Poughskeepsie, 1986).

${ }^{4}$ Eva-Maria Engel and Vera Müller, "Verschlüsse der Frühzeit: Erstellung einer Typologie," GM 178 (2000), 41-43, Abb. 4, T. 1; Jean-Pierre Pätznick, Die Siegelabrollungen und Rollsiegel der Stadt Elephantine im 3. Jahrtausend v. Chr.: Spurensicherung eines archäologischen Artefaktes (Oxford, 2005), 56-57, Typ Tv.1, Taf. XII. At Abydos-South, double-winged temple doors were sealed by 


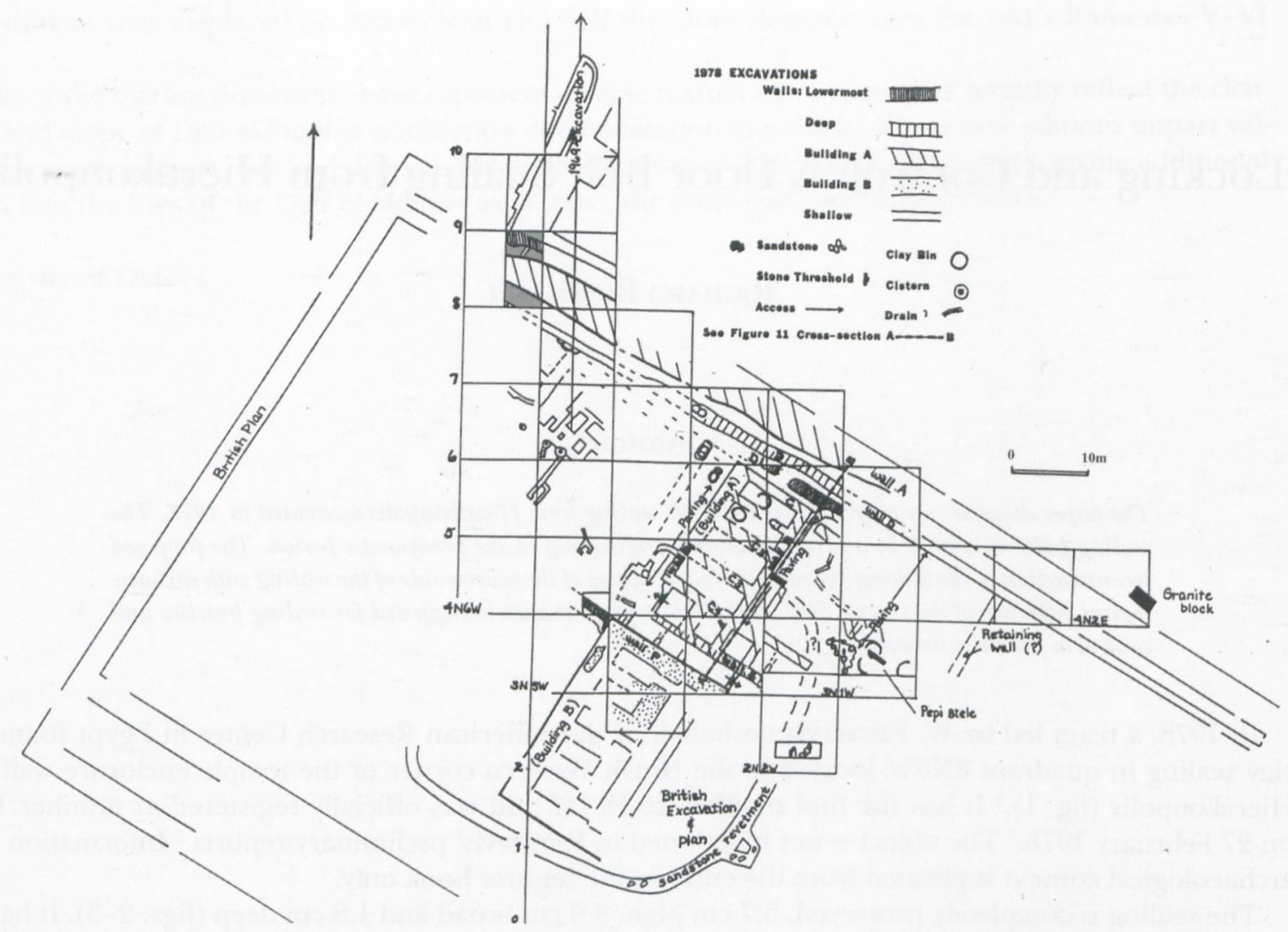

Fig. 1. Location of quadrant 8 N6W (shaded grey) in the temple area of Hierakonpolis (drawing after Fairservis, Hierakonpolis Project Season January to March 1978, fig. 6).

object presented here is the impression of the cord. One could argue that the cord was used in addition to the bolt to strengthen the construction or, perhaps, for magical purposes given that the use of seals and amulets in Egypt and the Near East often overlaps. ${ }^{5}$ However, there is archaeological evidence for a more compelling explanation.

A still useful book for understanding the mechanics of Egyptian doors is Otto Königsberger's Die Konstruktion der ägyptischen Tür. Königsberger demonstrates that one option for locking one-winged doors is with a bolt sliding through a cramp on the wing and into a hole in the thickness of the door. ${ }^{6}$ A hooked end prevented the bolt from slipping out of the L-shaped cavity in the wall. At the other end, the bolt was pierced for a cord with which it was pulled out of the wall to lock the door. Without the

a sealing attached to the metal cramp on the door, see Josef Wegner, The Mortuary Temple of Senwosret III at Abydos (New Haven, 2007), 317-23, fig. 135, 147, and 148. Compare also Erhart Graefe, "Die Versiegelung der Naostür (Die bisherige falsche Erklärung des Schriftzeichens [V2])," MDAIK 27 (1971), 147-55. The late Middle Kingdom sealing corpus from Elephantine does not include door bolt sealings, see Cornelius von Pilgrim, Elephantine XVIII: Untersuchungen in der Stadt des Mittleren Reiches und der Zweiten Zwischenzeit (Mainz, 1996), 234-74.

${ }^{5}$ Willeke Wendrich, "Entangled, connected or protected? The power of knots and knotting in ancient Egypt," in Kasia Szpakowska, ed., Through a Glass Darkly: Magic, Dreams and Prophecy in Ancient Egypt (Swansea, 2006), 243-70; Ilona Regulski, Kim Duistermaat and Peter Verkinderen, eds., Seals and Sealing Practices in the Near East: Developments in Administration and Magic from Prehistory to the Islamic Period (Leuven, 2012).

${ }^{6}$ Otto Königsberger, Die Konstruktion der ägyptischen Tür (Glückstadt, 1936), 49-53. 


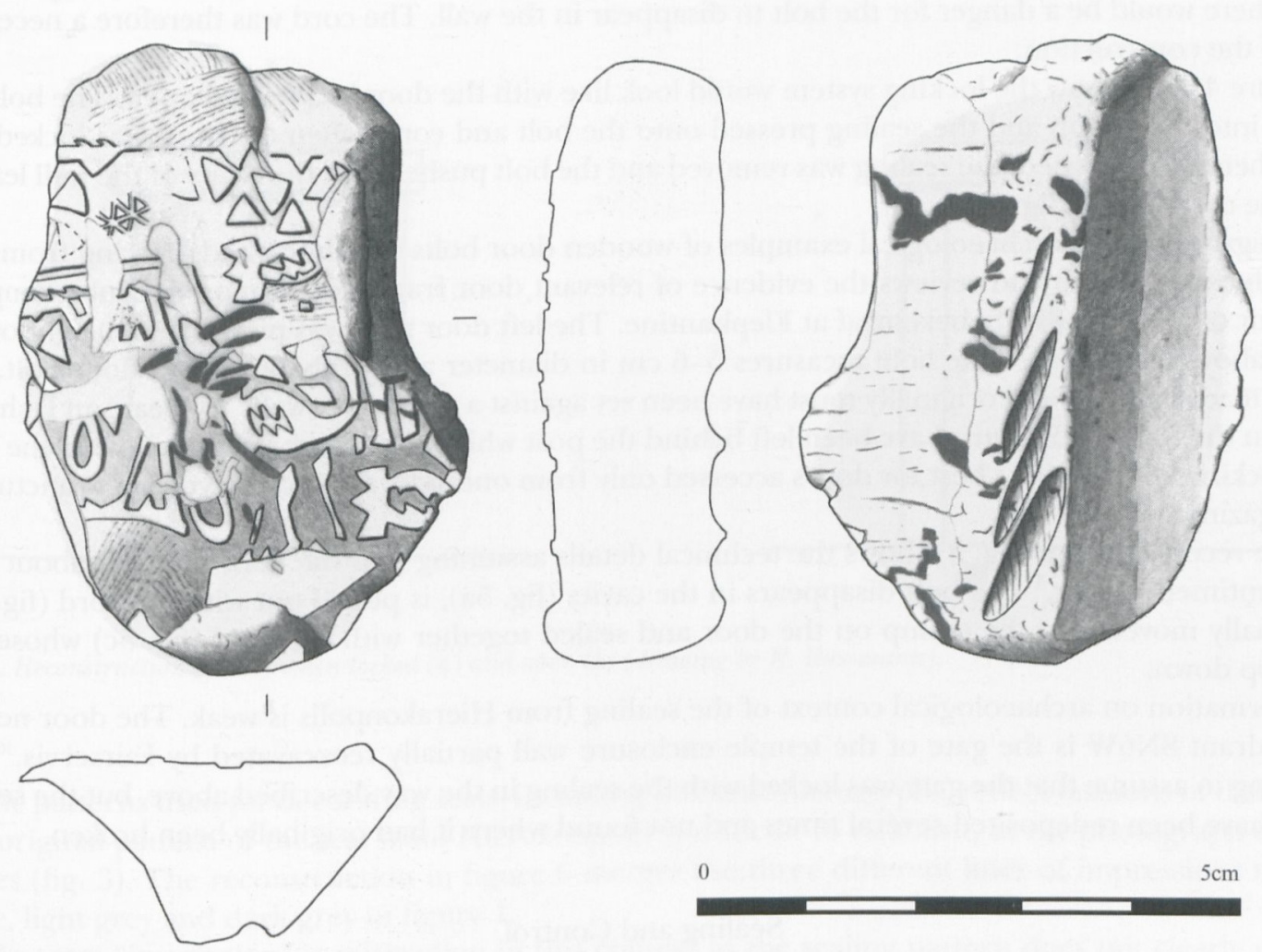

Fig. 2. Sealing 114, magazine of Elkab, find number 26-78-118 (drawing by R. Bussmann and C. von Elm).
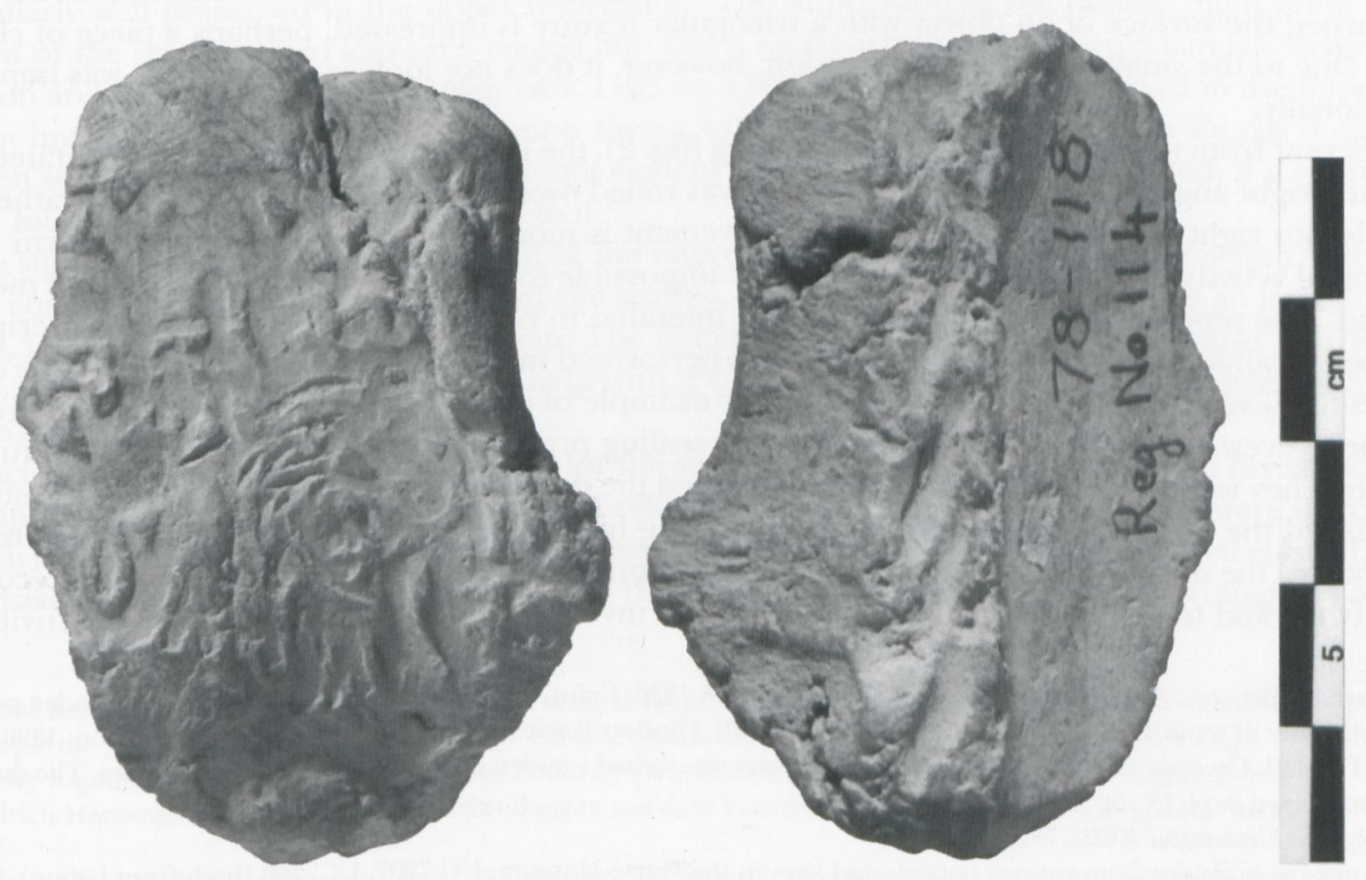

Fig. 3. Sealing 114 from Hierakonpolis, magazine of Elkab, find number 26-78-118 (photograph by R. Bussmann). 
cord, there would be a danger for the bolt to disappear in the wall. The cord was therefore a necessary part of the construction.

Figure 4 shows how the locking system would look like with the door locked and open. The bolt was pulled into the cramp and the sealing pressed onto the bolt and cord, when the door was locked (fig. 4a). When it was opened, the sealing was removed and the bolt pushed into the cavity of the wall leaving only the cord visible (fig. 4b).

Königsberger lists archaeological examples of wooden door bolts with hook and piercing from Deir el-Medine and Kahun and reviews the evidence of relevant door framings. ${ }^{7}$ A more recent example is the door of the shrine of Sobekemzaf at Elephantine. The left door post was pierced at a height of one meter above floor level. ${ }^{8}$ The hole measures $5-6 \mathrm{~cm}$ in diameter and probably held a door bolt. The post is made of stone and originally must have been set against a mud-brick wall. To create an L-shaped cavity in the wall, a hole must have been left behind the post which was larger than the hole in the post. This locking system works best for doors accessed only from one side, a situation typical of sanctuaries or magazines.

The reconstruction (fig. 5) shows the technical details assuming that the door bolt was about eighteen centimetres long. ${ }^{9}$ The bolt disappears in the cavity (fig. 5a), is pulled out with the cord (fig. 5b), and finally moved into the cramp on the door and sealed together with the cord (fig. $5 \mathrm{c}$ ) whose lose ends lop down.

Information on archaeological context of the sealing from Hierakonpolis is weak. The door nearest to quadrant $8 \mathrm{~N} 6 \mathrm{~W}$ is the gate of the temple enclosure wall partially reexcavated by Fairservis.$^{10}$ It is tempting to assume that the gate was locked with the sealing in the way described above, but the sealing might have been redeposited several times and not found where it had originally been broken.

\section{Sealing and Control}

Three overlapping lines of impressions run over the front. Parts of the surface are eroded and disturbed by the impression of what seems to be a bundle of grass or similar organic material. In the upper left corner, the surface of an object with a triangular texture is impressed, perhaps a piece of cloth or a net. Due to the small size of the impression, however, it does not look as if the object was impressed intentionally.

Different from the presentation in the drawing (fig. 2), the inscription was originally orientated vertically at a right angle to the door bolt. The seal was rolled over the clay from top to bottom rather than from left to right. Physically, the top down movement is more convenient for the human arm than a horizontal activity. The sealing pattern is almost impossible to decipher and probably was not meant to be read. The repeated rolling might have been intended to cover the entire surface with inscriptions, but the overall impression is that the sealing was performed mechanically, rapidly and with little care of the result. Given that sealing in Egypt today, for example of a magazine, is performed in the presence of others, eyewitnesses were presumably key for sealing practice in Pharaonic Egypt, too, to function socially. They would have been able to tell who sealed the door. In other words, the face-to-face situation established the actual mechanism of control allowing hierarchies and responsibilities to be acted out. In contrast, the difficult-to-decipher seal inscriptions probably played a subordinate role for recording, identifying, and tracking down the names of officials involved in a chain of administrative activities.

\footnotetext{
7 Bernard Bruyère, Rapport sur les fouilles de Deir el Médineh 1926 (Cairo, 1927), 34, no. 14, fig. 19 (lock with wooden post from burial chamber of tomb 1069) and 8, fig. 60 (from tomb 210); Flinders Petrie, Kahun, Gurob, and Hawara (London, 1890), 24, pl. 9, no. 11 and 21. On page 24, Petrie says that "the doorways mostly had wooden doors, and often also door cases. The door bolts found are shown in pl. IX, fig. 21."

${ }^{8}$ Pilgrim, Elephantine XVIII, 152, Abb. 60b.

${ }^{9}$ Compare examples from various periods and sites in the Petrie Museum: UC 7297, UC7298 (both from Lahun), UC7826 (Gurob), UC27980 (Hawara), UC63787, UC63790-63792 (provenance unknown, UC63790 with cord attached).

${ }^{10}$ Fairservis, Hierakonpolis Project Season January to March 1978, 7-10. However, quadrant 8N6W is not described.
} 


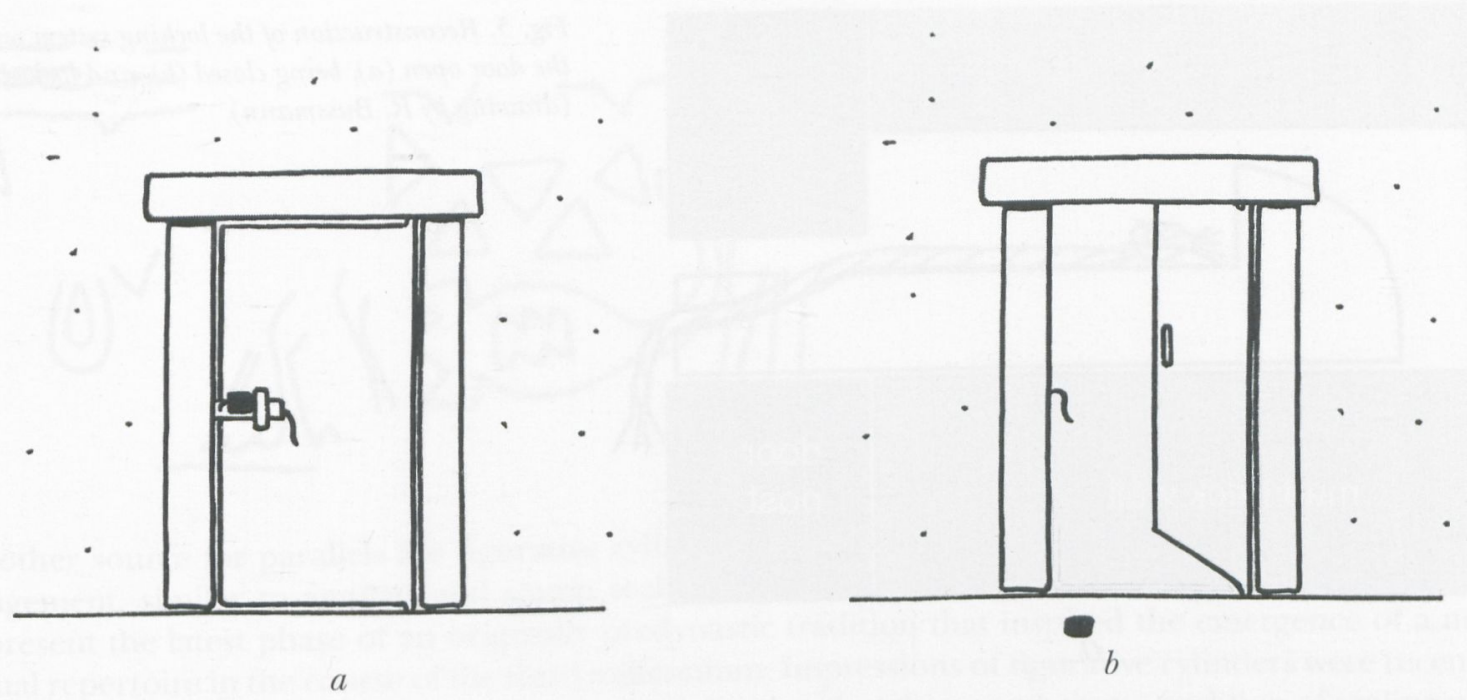

Fig. 4. Reconstruction of door when locked (a) and open (b) (drawing by R. Bussmann).

The patterns used for decorating seals, including phonetic hieroglyphs, reflect fashions of their time. The original pattern of the seal from Hierakonpolis is difficult to establish, as the photograph demonstrates (fig. 3). The reconstruction in figure 6 merges the three different lines of impressions marked white, light grey and dark grey in figure 1 .

The term "inscription" is misleading in this context as the sealing pattern does not clearly refer to phonetic script. The clearest sign is the scorpion on the right hand side. Above it are a series of decorative triangles and a double jagged line bordering the sealing pattern at the top. This arrangement is particularly well preserved in the upper impression. The impression in the middle (light grey) shows in front of the scorpion two legs on a jagged line and a loop surrounded by two triangles. Behind the scorpion are two enigmatic vertical elements. Legs on a jagged line are also preserved in the upper and bottom impression. The bottom impression shows, however, three legs (perhaps a fourth is eroded) between scorpion and loop. It is therefore not evident whether the animal represented, if it is one, has two or four legs and how the loop relates to it. ${ }^{11}$

The signs at the beginning and the end of the impressions do not overlap. It is likely that only parts of the complete pattern are impressed on the sealing. The preserved sequence, with all its miniature details, is executed on a length of ca. $4 \mathrm{~cm}$. The diameter of the cylinder used measures therefore at least $1.3 \mathrm{~cm}$. The jagged lines offer some help with reconstructing the height of the cylinder seal, probably around $2.5 \mathrm{~cm}$.

Exact parallels for the string of signs and for the shape of the scorpion do not exist to my knowledge, but Kaplony's "Tiersiegel" are a good point of reference in general. ${ }^{12}$ Similar patterns were discovered in Predynastic and First Dynasty contexts at cemetery U at Abydos, ${ }^{13}$ the settlement at Tell el-Iswid, ${ }^{14}$ and at Hierakonpolis, ${ }^{15}$ although the sealings from the latter site are not dated by archaeological context.

11 Ilona Regulski, A Palaeographic Study of Early Writing in Egypt (Leuven, 2010), offers the richest documentation for parallels, for example the group $\mathrm{E}$ (mammals) and $\mathrm{G}$ (birds). However, none of the signs combines an animal with a loop.

${ }_{12}$ Peter Kaplony, Die Inschriften der ägyptischen Frühzeit I (Wiesbaden, 1963), 10, with abb. 53-71 on pls. 24-28.

${ }^{13}$ Ulrich Hartung, "Prädynastische Siegelabrollungen aus dem Friedhof U in Abyodos (Umm el-Qaab)," MDAIK 54 (1998), 187-217.

${ }^{14}$ Ilona Regulski, “Seal impressions from Tell el-Iswid," in Béatrix Midant-Reynes and Nathalie Buchez, eds., Tell el-Iswid: 2006-2009 (Cairo, 2014), 232-33, fig. 2.

15 Richard Bussmann, "Seals and Seal Impressions from Hierakonpolis," Egyptian Archaeology 38 (2011), 17-19; idem, 


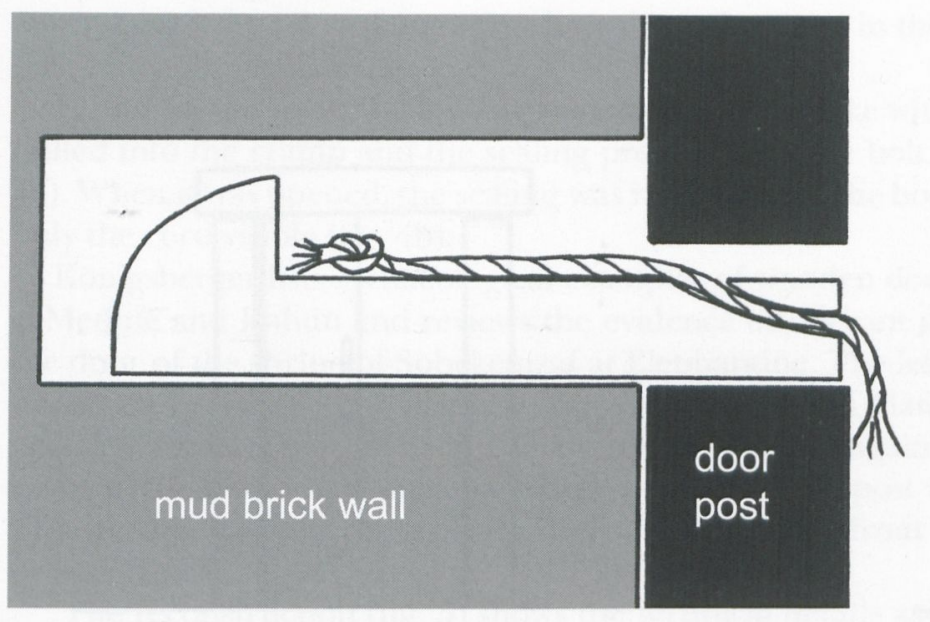

Fig. 5. Reconstruction of the locking system with the door open (a), being closed (b), and locked (c) (drawing by R. Bussmann).

$a$
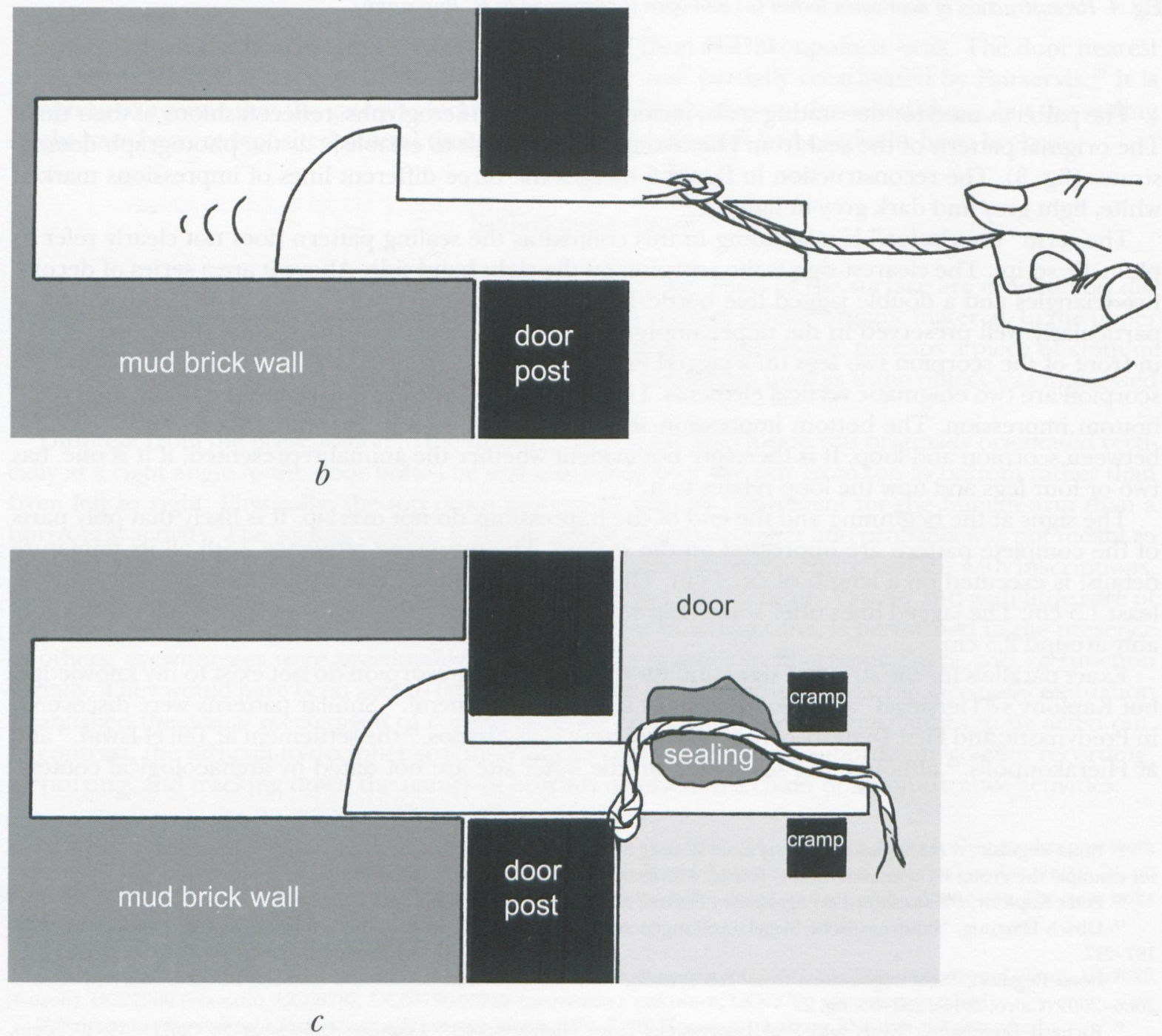


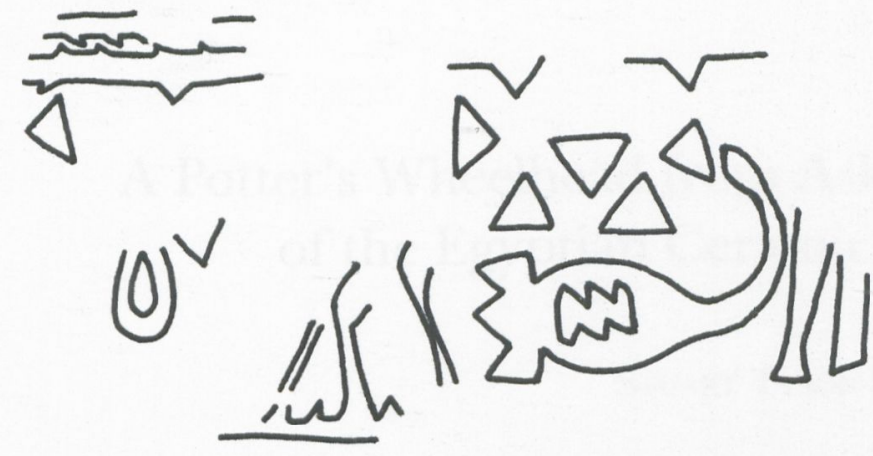

Fig. 6. Reconstruction of the sealing pattern (drawing by R. Bussmann).

Another source for parallels are figurative cylinders. They display an imagery, often in tête-bêche arrangement, similar to amulets and stamp seals of the late Old Kingdom. ${ }^{16}$ Figurative cylinders may represent the latest phase of an originally predynastic tradition that inspired the emergence of a new visual repertoire in the course of the third millennium. Impressions of figurative cylinders were recently found in a Fourth Dynasty context at Sheikh Said showing that the non-phonetic tradition of sealing patterns may well have continued throughout the third millennium. ${ }^{17}$ James Quibell and Frederik Green found what looks like another impression of a figurative cylinder at Hierakonpolis which would back up a dating of the piece discussed here to the Old Kingdom. ${ }^{18}$ However, a definite decision on when the cylinder seal was cut and used to lock the temple gate is difficult to take.

\section{Conclusion}

The reconstruction proposed here combines sealing typology and archaeological evidence of door bolts and frames. The sealing from Hierakonpolis was attached to a door whose bolt was pulled out of the wall with a cord. The sealing pattern is tentatively dated to the predynastic period, although a later date cannot be excluded. The sealing may have been attached originally to the North Eastern gate of the temple enclosure wall.

The benefit of analysing the reverse side of sealings is to anchor administration in the material world. It is suggested here that the public performance of locking and sealing a door establishes the relevant social mechanism of control. Sealing is a type of administrative practice physically related to the body and relying on visual rather than written communication. Other than the visual properties of the hieroglyphic script, names and titles mentioned in seal inscriptions are irrelevant for sealing practice to be effective.

\section{University College London}

\footnotetext{
“Administration without writing," Nekhen News 25 (2013), 23-24.

${ }^{16}$ Henry George Fischer, "Old Kingdom Cylinder Seals for the Lower Classes," in Cyril Aldred, Henry George Fischer, Herman de Meulenaere, Birgit Nolte and Edna Russmann, Ancient Egypt in the Metropolitan Museum Journal, Volumes 1-11 (1968-1976) (New York, 1977), 51-62; Peter Kaplony, Die Rollsiegel des Alten Reiches II. Katalog der Rollsiegel (Brussels, 1981), 151-83; André Wiese, Die Anfänge der ägyptischen Stempelsiegel-Amulette. Eine typologische und religionsgeschichtliche Untersuchung zu den „Knopfsiegeln“ und verwandten Objekten der 6. bis frühen 12. Dynastie (Fribourg and Göttingen, 1996); Ulrike Dubiel, Amulette, Siegel und Perlen. Studien zu Typologie und Tragesitte im Alten und Mittleren Reich (Fribourg and Göttingen, 2008).

${ }_{17}$ Harco Willems, Stefanie Vereecken, Lucia Kujper, Bart Vanthuyne, Elena Marinova, Veerle Linseele, Gert Verstraeten, Stan Hendrickx, Merel Eyckerman, Ann Van den Broek, Wim Van Neer, Janine Bourriau, Peter French, Christoph Peeters, Véronique de Laet, Sophie Mortier, Zoë De Kooning, “An industrial site at Al-Shaykh Sa'̄ìd/Wādī Zabayda,” Ägypten und Levante 19 (2009), 293-331, for clay sealings see pages 313-15 and pl. IV.

${ }^{18}$ Quibell and Green, Hierakonpolis II, pl. 71, no. 40.
} 